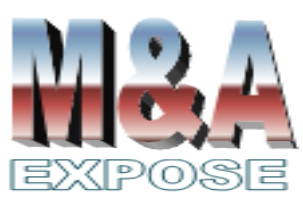

http://jurnal.usahid.ac.id/index .php/accounting
${ }^{1}$ Magister Manajemen Universitas Sahid saepuiaman@gmail.com ${ }^{2}$ Fakultas Ekonomi dan Bisnis Universitas Sahid Jakarta levydamm@yahoo.co.id ${ }^{3}$ Magister Manajemen Universitas Sahid

\section{Analisis Kinerja Bank Syariah Penerima Setoran Penyelenggaraan Ibadah Haji}

\author{
Saepujaman Saepujaman ${ }^{1}$, Levyda Levyda ${ }^{2}$, \\ Heri Ispriyahadi ${ }^{3}$
}

\begin{abstract}
Abstrak
Untuk meningkatkan kinerja bank syariah, pemerintah mengeluarkan Aturan Penyetoran Biaya Penyelenggaraan Ibadah Haji (APBIP) yang mengalihkan penyetoran biaya penyelenggaraan ibadah haji dari bank konvensional ke bank syariah atau bank yang memiliki layanan syariah. Pengaruh peraturan pemerintah terhadap kinerja bank syaria masih belum jelas sehingga perlu diuji. Selain APBIP, kinerja bank diduga dipengaruhi oleh faktor-faktor spesifik perbankan seperti Capital Adequacy Ratio (CAR), Financing to Deposit Ratio (FDR), dan Biaya Operasional Terhadap Pendapatan Operasional (BOPO) terhadap Return on Assets (ROA) pada bank syariah. Penelitian ini bertujuan untuk mengkaji pengaruh Aturan Penyetoran Biaya Penyelenggaraan Ibadah Haji (APBIP), CAR, FDR, BOPO terhadap ROA di bank-bank syariah penerima setoran biaya penyelenggaraan haji, secara parsial dan simultan. Teknis analisis yang digunakan adalah regresi berganda dengan dummy variable. Kesimpulannya ROA, FDR dan BOPO berpengaruh terhadap ROA, sedangkan CAR tidak berpengaruh terhadap ROA.
\end{abstract}

Kata kunci : APBIP, CAR, FDR, BOPO, ROA.

\section{Abstract}

To improve the performance of sharia banks, the government issued the Rules of Inclusion of Hajj Operation Cost from conventional banks to sharia banks or banks that have sharia services. The influence of government regulations on the performance of sharia banks is still unclear. Influence of banking specific factors such as Capital Adequacy Ratio (CAR), Financing to Deposit Ratio (FDR), and Operational Cost to Operating Income Ratio to Return on Assets (ROA) in syariah bank, are still unclear. This study aims to examine the effect of the Rules of Deposit of Hajj Operation Cost (RDHOC) towards ROA and to reexamine the effect of CAR, FDR, BOPO on ROA in syariah banks recipients of Hajj, partially and simultaneously. Analytical technic used was multiple regression with dummy variable. The conclusion is ROA, FDR and BOPO have influence towards ROA, while CAR has no effect to $R O A$.

Keywords: RDHOC, CAR, FDR, BOPO, ROA. 
Analisis Kinerja Bank Syariah ...

Saepujaman Saepujaman, Levyda Levyda \& Heri Ispriyahadi

\section{PENDAHULUAN}

Bank syariah memiliki posisi yang cukup penting bagi perekonomian Indonesia karena kemaslahatan-kemaslahatan yang dimilikinya. Menurut Halim (2012) ada ada 3 kemaslahatan bank syariah. Pertama, bank syariah menggunakan transaksi di sektor riil sehingga dampaknya lebih nyata dalam mendorong pertumbuhan ekonomi. Kedua, pada bank syariah tidak terdapat produk yang bersifat spekulatif (gharar) sehingga mempunyai daya tahan yang kuat dari pengaruh krisis keuangan global. Ketiga, sistem bagi hasil (profitloss sharing) membawa manfaat yang lebih adil bagi semua pihak, baik bagi pemilik dana (deposan), pengusaha (debitur) maupun pihak bank selaku pengelola dana.

Berbagai upaya dilakukan untuk meningkatkan kinerja bank syariah, baik yang berupa upaya regulatif, edukatif maupun upaya sinergi antar lembaga. Salah satu bentuk upaya sinergi antar lembaga adalah peraturan Menteri Agama Nomor 30 tahun 2013 tentang Bank Penerima Setoran Biaya Penyelenggaraan Ibadah Haji (BPS-BPIH). Pada peraturan tersebut setoran biaya haji dialihkan dari bank konvensional ke bank syariah atau bank konvensional yang memiliki layanan syariah. Namun hanya bank syariah yang memenuhi syarat yang dapat menjadi Bank Penerima Setoran Biaya Penyelenggaraan Ibadah Haji (BPS-BPIH). Masuknya dana setoran BPIH mendorong peningkatan jumlah Dana Pihak Ketiga (DPK).

Gambar 1. Pertumbuhan Dana Pihak Ketiga (DPK)

Bank Umum Syariah Penerima Setoran PIH 2012 - 2015 (Milyar rupiah)

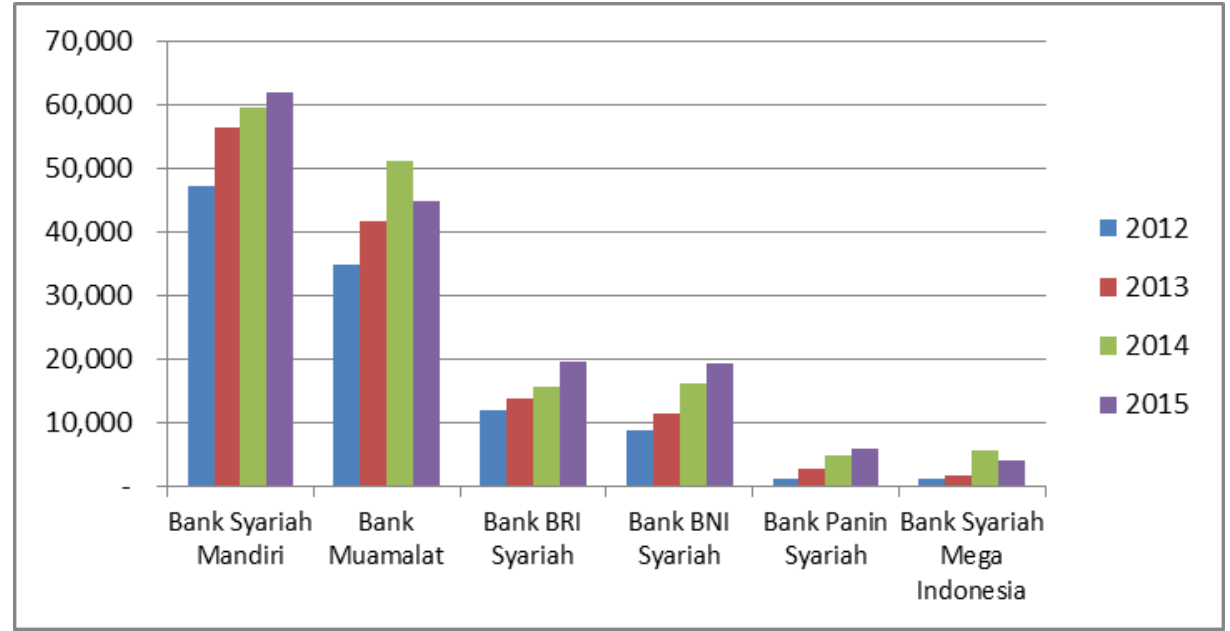

Sumber: Rangkuman Laporan Tahunan Bank Syariah Mandiri, Bank Muamalat,

Bank BRI Syariah, Bank BNI Syariah, Bank Panin Syariah dan Bank Syariah Mega Indonesia.

Naceur dan Omran (2010) mengemukakan bahwa regulasi pemerintah berpengaruh pada kinerja bank, hasil analisis menunjukkan keberagaman. Oleh karena itu masih perlu dilakukan kajian pengaruh peraturan Menteri Agama Nomor 30 tahun 2013 terhadap ROA.

Pada penelitian terdahulu pengaruh faktor-faktor spesifik perbankan atau faktorfaktor internal bank seperti Capital Adequacy Ratio (CAR), Financing to Deposit Ratio (FDR) dan Rasio Biaya Operasional terhadap Pendapatan Operasional (BOPO) terhadap ROA, sangat beragam. Oleh karena itu pengaruh faktor-faktor tersebut terhadap ROA, masih perlu diteliti lagi. Penelitian ini bertujuan untuk menguji pengaruh Aturan Penyetoran Dana Biaya 
Penyelenggaraan Ibadah Haji (APBPIH), Capital Adequacy Ratio (CAR), Financing to Deposit Ratio (FDR), Rasio Biaya Operasional Terhadap Pendapatan Operasional (BOPO) terhadap Return on Assets (ROA) secara parsial dan simultan di Bank Umum Syariah Penerima Setoran BPIH. Uji parsial dan simultan dilakukan secara keseluruhan dan secara individu.

\section{TINJAUAN PUSTAKA}

Terminologi Bank Umum Syariah Penerima Setoran Biaya Penyelenggaraan Ibadah Haji (BPS-BPIH) dimunculkan oleh Kementerian Agama RI melalui Dirjen Penyelenggaraan Haji dan Umrah (PHU) selaku penyelenggara kegiatan Ibadah haji bagi umat Islam di Indonesia. Dalam pelaksanaanya melayani serta menerima pembayaran Biaya Penyelenggaraan Ibadah Haji (BPIH) dari para calon jemaah haji (calhaj) Dirjen PHU membutuhkan mitra yang memiliki kapabilitas untuk menerima dan menampung dana pembayaran dari calon haji tersebut. Untuk itu Dirjen PHU menggandeng bank untuk menjadi Bank Penerima Setoran Biaya Penyelenggaraan Ibadah Haji (BPS-BPIH). Bank yang terpilih oleh Dirjen PHU untuk menerima setoran BPIH dari calhaj lah yang disebut sebagai BPS-BPIH. Proses seleksi dan penentuan persyaratan dilakukan oleh Dirjen PHU dalam menentukan BPS-BPIH. Ketentuan mutakhir sehubungan dengan hal ini adalah Peraturan Menteri Agama No 30 tahun 2013 tentang Bank Penerima Setoran Biaya Penyelenggaraan Ibadah Haji (BPS-BPIH).

Berdasarkan proses seleksi oleh Direktorat Jenderal Penyelenggaraan Haji dan Umrah (PHU) kementerian Agama RI. Terpilih sejumlah bank yang menjadi BPS-BPIH seperti tercantum pada tabel 2.

Tabel 2. Bank Penerima Setoran Biaya Penyelenggaraan Ibadah Haji (BPS-BPIH)

\begin{tabular}{lll}
\hline Bank Umum Syariah (BUS) & $\begin{array}{l}\text { Bank Umum Nasional Dengan } \\
\text { Layanan Syariah/Unit Usaha } \\
\text { Syariah (UUS) }\end{array}$ & Bank Transito \\
\hline Bank Syariah Mandiri & Bank BTN & Bank Mandiri \\
Bank Muamalat & Bank Permata & Bank BRI \\
Bank BRI Syariah & Bank CIMB Niaga & Bank BNI \\
Bank BNI Syariah & Bank Sumut & \\
Bank Panin Syariah & Bank DKI & \\
Bank Mega Syariah & Bank Jateng & \\
& Bank Jatim & \\
& Bank Kepri & \\
& Bank SumselBabel & \\
& Bank Nagari & \\
& Bank Aceh & \\
\hline
\end{tabular}

Sumber : Menag Umumkan 17 Bank Penerima Setoran Haji (www.republikaonline.co.id)

Kinerja bank merupakan hal yang kompleks. Banyak faktor yang mempengaruhi kinerja bank. Menurut Hassan \& Bashir (2003), analisis kinerja bank dalam analisis faktor internal dan eksternal. Analisis faktor internal adalah analisis rasio keuangan sedangkan 
analsis faktor eksternal adalah analisis pangsa pasar, kepatuhan pada aturan dan kepercayaan publik. Ongore dan Kusa (2013) menyimpulkan bahwa kinerja bank yang diukur dengan ROA, ROE, NIM ditentukan oleh faktor-faktor spesifik perbankan seperti capital adequacy, kualitas asset, manajemen efisiensi, manajemen likuiditas. Kinerja bank diukur dengan berbagai ukuran. Hassan \& Bashir (2003) menyebutkan ada empat pengukuran yaitu Net Non Interest Margin (NIM), the bank's before-tax profit over total assets (BTP/TA), kinerja keseluruhan adalah ROA dan ROE. ROA menunjukkan pendapatan per Rupiah dari asset. ROA sangat penting karena mengambarkan kemampuan manajemen bank untuk memanfaatkan dana bank dan menginvestasikannya pada hal-hal yang mendatangkan keuntungan (Hassan \& Bashir, 2003). Lebih lanjut ROA ditentukan oleh kebijakan bank, kebijakan pemerintah dan kondisi ekonomi.

Sahara (2013) menemukan bahwa ROA dipengaruhi oleh Bank Indonesia Rate dan Gross Domesic Bruto (GDP) sedangkan Swandayani \& Kusumaningtias (2012) menemukan bahwa faktor-faktor eksternal yang mempengaruhi ROA di bank syariah adalah inflasi, nilai tukar valas dan jumlah uang yang beredar. inflasi, suku bunga Sertifikat Bank Indonesia, nilai tukar valas dan jumlah uang beredar secara simultan berpengaruh terhadap ROA sedangkan secara parsial ROA ditentukan oleh suku bunga dan nilai tukar valas. Selain GDB, suku bunga SBI, nilai tukar valas, inflasi, faktor eksternal yang perlu dipertimbangkan adalah peraturan pemerintahg. Menurut Ben Naceur \& Omran (2010) peraturan pemerintah dan institusi mempengaruhi kinerja bank.

Aturan Aturan Penyetoran Dana Biaya Penyelenggaraan Ibadah Haji (APBPIH), merupakan kebijakan pemerintah untuk mendukung perkembangan bank syariah di Indonesia. APBPIH meningkatkan Dana Pihak Ketiga (DPK) di Bank Syariah Penerima Biaya Penyelenggaraan Ibadah Haji. Karena DPK meningkat maka kemampuan bank untuk menyalurkan dana ke sektor-sektor yang berpotensi meningkatkan keuntungan, akan semakin besar. Oleh karena itu, hipotesis penelitian ini adalah :

$\mathrm{H}_{1}$ : APBPIH berpengaruh posistif terhadap ROA.

Peningkatan pembiayaan yang dilakukan oleh bank, selain menciptakan peluang keuntungan (profit) juga kerugian. Capital Adequacy Ratio (CAR) merupakan bentuk upaya menjaga dan mengontrol resiko bank. Capital Adequacy Ratio (CAR) ini adalah rasio solvabilitas yang wajib dilaporkan oleh setiap Bank di Indonesia kepada regulator keuangan nasional (OJK) secara berkala dalam rangka pengawasan kesehatan perbankan. Rasio ini merupakan alat analisis yang digunakan untuk mengetahui berapa jumlah modal yang memadai untuk menunjang kegiatan operasionalnya dan cadangan untuk menyerap kerugian yang mungkin terjadi. Capital Adequacy Ratio (CAR) mempengaruhi jumlah dana yang dapat dipinjamkan kepada pihak lain. Dengan demikian bila CAR naik maka kesempatan untuk mendapatkan keuntungan semakin tinggi, demikian pula sebaliknya (Olarewaju, 2016). Menurut Amalia (2015), Hakiim \& Rafsanjani (2016) dan Harianto (2017) CAR tidak berpengaruh terhadap ROA. Kurniati dan Purwohandoko (2017) menemukan CAR berpengaruh negatif terhadap ROA. Meskipun banyak penelitian tentang pengaruh CAR terhadap ROA terhadap ROA sehingga perlu diuji lagi. Hipotesis yang diajukan : $\mathrm{H}_{2}$ : Capital Adequacy Ratio (CAR) berpengaruh positif pada ROA.

FDR adalah rasio keuangan yang mengukur tingkat kesehatan perbankan berdasarkan banyaknya nilai pembiayaan yang diberikan bank kepada masyarakat dibandingkan dengan jumlah deposit yang disetorkan masyarakat. Apabila suatu bank memiliki tingkat FDR diatas jumlah maksimal yang telah ditentukan oleh pemerintah, dapat 
di simpulkan bahwa tingkat kesehatan bank tersebut tidak baik karena memberikan pembiayaan dalam jumlah yang terlalu banyak. Menurut Amalia (2015) dan Harianto (2017) FDR tidak berpengaruh terhadap ROA. Menurut Hakiim \& Rafsanjani (2016) dan Kurniati dan Purwohandoko (2017) menemukan FDR berpengaruh negatif terhadap ROA. Dengan demikian hipotesis pada penelitian ini adalah :

$\mathrm{H}_{3}$ : Financing to Deposit Ratio (FDR) berpengaruh positif pada ROA.

Rasio Biaya Operasional Terhadap Pendapatan Operasional (BOPO) adalah rasio yang hitung untuk mengukur perbandingan antara biaya operasional dan pendapatan operasional. Operasional bank dapat dikategorikan efisien bila tingkat BOPO nya rendah. BOPO yang tinggi dapat menggerus potensi keuntungan yang akan didapatkan oleh sebuah bank. Menurut Amalia (2015) dan Harianto (2017) BOPO berpengaruh terhadap ROA. Hakiim \& Rafsanjani (2016) menemukan BOPO berpengaruh negatif terhadap ROA. Karena belum ada kesepakatan maka perlu diuji lagi dan hipotesis penelitian ini adalah :

$\mathrm{H}_{4}$ : Rasio Biaya Operasional Terhadap Pendapatan Operasional (BOPO) berpengaruh positif pada ROA.

\section{METODE PENELITIAN}

Penelitian ini menggunakan sampel jenuh yaitu seluruh bank umum syariah yang terpilih menjadi Penerima Setoran Biaya Penyelenggaraan Ibadah Haji (BPS-BPIH) oleh Dirjen Penyelenggaraan Haji dan Umrah (PHU) Kementerian Agama Republik Indonesia, sebanyak enam bank yaitu : Bank Syariah Mandiri, Bank Muamalat, Bank BRI Syariah, Bank BNI Syariah, Bank Panin Dubai Syariah dan Bank Mega Syariah.

Jenis data dalam penelitian ini adalah data sekunder berupa rasio-rasio keuangan bank umum syariah dan bank konvensional, hasil olahan laporan keuangan Bank Umum Syariah Penerima Setoran dana BPIH (BPS-BPIH) periode 2011-2016 (kwartal 3). Penelitian ini menggunakan data triwulanan pada periode tersebut. APBPIH merupakan data panel.

Aturan Penyetoran Dana Biaya Penyelenggaraan Ibadah Haji (APBPIH) merupakan variable nominal, sedangkan CAR,FDR, BOPO, dan ROA adalah variabel rasio sehingga penelitian ini menggunakan regresi berganda dengan variabel dummy. Untuk menguji pengaruh APBPIH, CAR,FDR, BOPO terhadap ROA secara parsial digunakan uji $t$, sedangkan uji f digunakan untuk menguji APBPIH, CAR,FDR, BOPO terhadap ROA secara simultan.

Model regresi dummy penelitian ini adalah:

di mana:

$$
\text { Yit }=\alpha+\beta_{1} X_{1 i t}+\beta_{2} X_{2 i t}+\beta_{3} X_{3 i t}+\beta_{4} X_{4 i t}+e_{i t}
$$

$$
\begin{array}{ll}
\mathrm{Y} & =\text { Variable dependen }- \text { Return On Assets (ROA) } \\
\mathrm{A} & =\text { Konstanta } \\
\mathrm{X}_{1} & =\text { Variabel independen 1 - Aturan Penyetoran Dana BPIH (APBPIH) } \\
\mathrm{X}_{2} & =\text { Variabel independen } 2 \text { - Capital Adequacy Ratio (CAR) } \\
\mathrm{X}_{3} & =\text { Variabel independen } 3-\text { Financing to Deposit Ratio (FDR) } \\
\mathrm{X}_{4} & =\text { Variabel independen 4 - BOPO } \\
\beta_{1(1,2 \ldots)} & =\text { Koefisien regresi masing-masing variabel independen } \\
\mathrm{e} & =\text { residual }
\end{array}
$$


Analisis Kinerja Bank Syariah ...

Saepujaman Saepujaman, Levyda Levyda \& Heri Ispriyahadi

Model estimasi penelitian ini adalah Least Squares Dummy Variable (LSDV). Selanjutnya dilakukan uji autokorelasi, uji heteroskedastisitas, dan uji otokorelasi. Setelah lolos uji prasyarat multikolinearitas, autokorelasi dan heteroskedastisitas, dilanjutkan dengan uji t dan uji f. Data diolah dengan bantuan software EViews 8.

\section{HASIL DAN PEMBAHASAN}

Agar model dapat digunakan sebagai alat prediksi yang baik, maka model harus bebas dari multikolinieritas, heteroskedasitas, otokorelasi dan normalitas. Hasil uji multikolinieritas, bahwa tidak ditemukan nilai koefisien korelasi yang lebih tinggi dari 0,8. Dengan demikian model yang dibangun bebas dari multikolineritas. Untuk uji autokorelasi, digunakan Breusch-Godfrey Serial Correlation LM Test, dan diperoleh hasil nilai probalitas Chi-Square sebesar 0,6058. Untuk uji heteroskedastisita, digunakan White Test. Hasil uji heteroskedasitas nilai probalitas Chi-Square adalah 0,1708. 0,6058 dan 0,1708 lebih tinggi dari a 0,05 maka model dibangun bebas dari autokorelasi dan heteroskedastisitas.

Hasil regresi data panel model Fixed Effect untuk seluruh bank syariah penerima setoran BPIH sebagai berikut :

Tabel 3. Hasil Regresi Data Panel Seluruh BPS-BPIH

\begin{tabular}{|c|c|c|c|c|}
\hline Variable & Coefficient & Std. Error & t-Statistic & Prob. \\
\hline$\overline{\mathrm{C}}$ & 8.336841 & 0.371171 & 22.46089 & 0.0000 \\
\hline APBPIH? & -0.252149 & 0.056030 & -4.500262 & 0.0000 \\
\hline CAR? & 0.001038 & 0.003411 & 0.304381 & 0.7613 \\
\hline FDR? & -0.008284 & 0.002324 & -3.564188 & 0.0005 \\
\hline BOPO? & -0.069832 & 0.002962 & -23.57518 & 0.0000 \\
\hline RESID? & 1.000000 & 0.047466 & 21.06770 & 0.0000 \\
\hline \multicolumn{5}{|l|}{ Fixed Effects (Cross) } \\
\hline BSM-C & $-8.76 \mathrm{E}-16$ & & & \\
\hline $\mathrm{BM}-\mathrm{C}$ & $-5.55 E-17$ & & & \\
\hline BRIS-C & $7.24 \mathrm{E}-17$ & & & \\
\hline $\mathrm{BNIS}-\mathrm{C}$ & $-1.42 \mathrm{E}-15$ & & & \\
\hline BPS-C & $-1.99 \mathrm{E}-15$ & & & \\
\hline BMS-C & $-2.65 E-15$ & & & \\
\hline \multicolumn{5}{|c|}{ Effects Specification } \\
\hline \multicolumn{5}{|c|}{ Cross-section fixed (dummy variables) } \\
\hline R-squared & 0.934070 & \multicolumn{2}{|c|}{ Mean dependent var } & 1.353333 \\
\hline Adjusted R-squared & 0.928879 & \multicolumn{2}{|c|}{ S.D. dependent var } & 1.051121 \\
\hline S.E. of regression & 0.280319 & \multicolumn{2}{|c|}{ Akaike info criterion } & 0.370576 \\
\hline Sum squared resid & 9.979495 & \multicolumn{2}{|c|}{ Schwarz criterion } & 0.603908 \\
\hline Log likelihood & -14.56976 & \multicolumn{2}{|c|}{ Hannan-Quinn criter. } & 0.465396 \\
\hline F-statistic & 179.9286 & \multirow{2}{*}{\multicolumn{2}{|c|}{ Durbin-Watson stat }} & 1.883209 \\
\hline Prob(F-statistic) & 0.000000 & & & \\
\hline
\end{tabular}

Persamaan regresi untuk memprediksi ROA adalah :

$\mathrm{ROA}_{\mathrm{it}}=8,3368-0,2522 \mathrm{APBPIH}_{\mathrm{it}}+0,0010 \mathrm{CAR}_{\mathrm{it}}-0,0083 \mathrm{FDR}_{\mathrm{it}}-0,0699 \mathrm{BOPO}_{\mathrm{it}}+\mathrm{e}$ 
Pengaruh Aturan Penyetoran Biaya Penyelenggaraan Ibadah Haji (APBPIH) terhadap ROA. Uji t statistik pada seluruh Bank Penerima Simpanan (BPS) menunjukkan hasil Aturan Penyetoran Biaya Penyelenggaraan Ibadah Haji (APBPIH) berpengaruh pada Return on Asset (ROA) dengan nilai probabilitas 0,000 . Artinya APBIH secara parsial berpengaruh negatif terhadap ROA. Kenaikan APBPIH meneyebabkan penurunan ROA. Hasil uji t-statistik untuk Bank Penerima Simpanan (BPS) Biaya Penyelenggaraan Ibadah Haji (BPIH) secara individu, adalah sebagai berikut :

Tabel 4. Hasil Uji t Statistik Individual BPS-BPIH

\begin{tabular}{|c|c|c|c|c|c|}
\hline Bank & $C\left(\beta_{0}\right)$ & APBPIH $\left(\beta_{1}\right)$ & $\operatorname{CAR}\left(\beta_{2}\right)$ & $\operatorname{FDR}\left(\beta_{3}\right)$ & $\mathrm{BOPO}\left(\beta_{4}\right)$ \\
\hline $\begin{array}{l}\text { Syariah } \\
\text { Mandiri }\end{array}$ & $7.020^{*}(0.000)$ & $-0.206^{*}(0.000)$ & $0.041^{*}(0.000)$ & $-0.003(0.496)$ & $-0.070^{\star}(0.000)$ \\
\hline $\begin{array}{l}\text { Bank } \\
\text { Muamalat }\end{array}$ & $2.730^{*}(0.000)$ & $-0.724^{*}(0.000)$ & $0.030^{* *}(0.020)$ & $0.013^{*}(0.000)$ & $-0.034^{*}(0.000)$ \\
\hline $\begin{array}{l}\text { BRI } \\
\text { Syariah }\end{array}$ & $8.617^{*}(0.000)$ & $-0.286^{\star}(0.000)$ & $-0.020^{\star *}(0.012)$ & $-0.007^{* *}(0.020)$ & $-0.072^{*}(0.000)$ \\
\hline $\begin{array}{l}\text { BNI } \\
\text { Syariah }\end{array}$ & $12.195^{\star}(0.000)$ & $0.107^{*}(0.002)$ & $-0.012^{* * *}(0.080)$ & $-0.024^{*}(0.000)$ & $-0.098^{*}(0.000)$ \\
\hline $\begin{array}{l}\text { Panin } \\
\text { Dubai } \\
\text { Syariah }\end{array}$ & $7.949^{*}(0.000)$ & $-0.034(0.681)$ & $0.001(0.756)$ & $-0.007^{\star}(0.000)$ & $-0.069^{*}(0.000)$ \\
\hline $\begin{array}{l}\text { Mega } \\
\text { Syariah }\end{array}$ & $9.492^{*}(0.000)$ & $-0.542^{*}(0.000)$ & $0.097^{\star}(0.000)$ & $0.001(0.692)$ & $-0.100 *(0.000)$ \\
\hline
\end{tabular}

${ }^{\star}$ : level signifikansi $1 \%,{ }^{* \star}$ : level signifikansi $5 \%,{ }^{* \star *}$ : level signifikansi $10 \%$.

Sumber: Data olahan EViews 8

Secara individu APBPIH (Aturan Penyetoran Biaya Penyelenggaraan Ibadah Haji) secara signifikan berpengaruh terhadap ROA dengan level signifikasi 1 persen di Bank Muamalat, BRI Syariah. BNI Syariah dan Mega Syariah. Pengaruh APBPIH positif terhadap ROA hanya BNI Syariah, sedangkan di bank lain berpengaruh negatif. Hasil penelitian mendukung Naceur \& Omran (2010) yang menyatakan bahwa kebijakan pemerintah memberikan pengaruh yang negatif dan signifikan terhadap ROA bank di Timur Tengah dan Afrika.

APBPIH menyebabkan naiknya Dana Pihak Ketiga (DPK). Namun tidak selalu menyebabkan naiknya ROA. Tergantung kemampuan masing-masing bank dalam menyalurkan DPK ke pembiayaan yang berkualitas, sehingga mampu meningkatkan ROA. Uji t statistic pada seluruh bank penerima BPIH, APBPIH, namun pada uji t secara individu menghasilkan pengaruh yang berbeda-beda. Pengaruh positif APBIP terhadap ROA, hanya terjadi BNI Syariah. Dengan demikaian hanya BNI Syariah yang mampu mengelola dengan baik peningkatan DPK karena APBIH. Kesimpulan ini didukung dengan naiknya Non Performing Financing (NPF) selama periode penelitian. 
Analisis Kinerja Bank Syariah ...

Saepujaman Saepujaman, Levyda Levyda \& Heri Ispriyahadi

Gambar 2. NPF BPS-BPIH 2011 Q1 - 2016 Q3

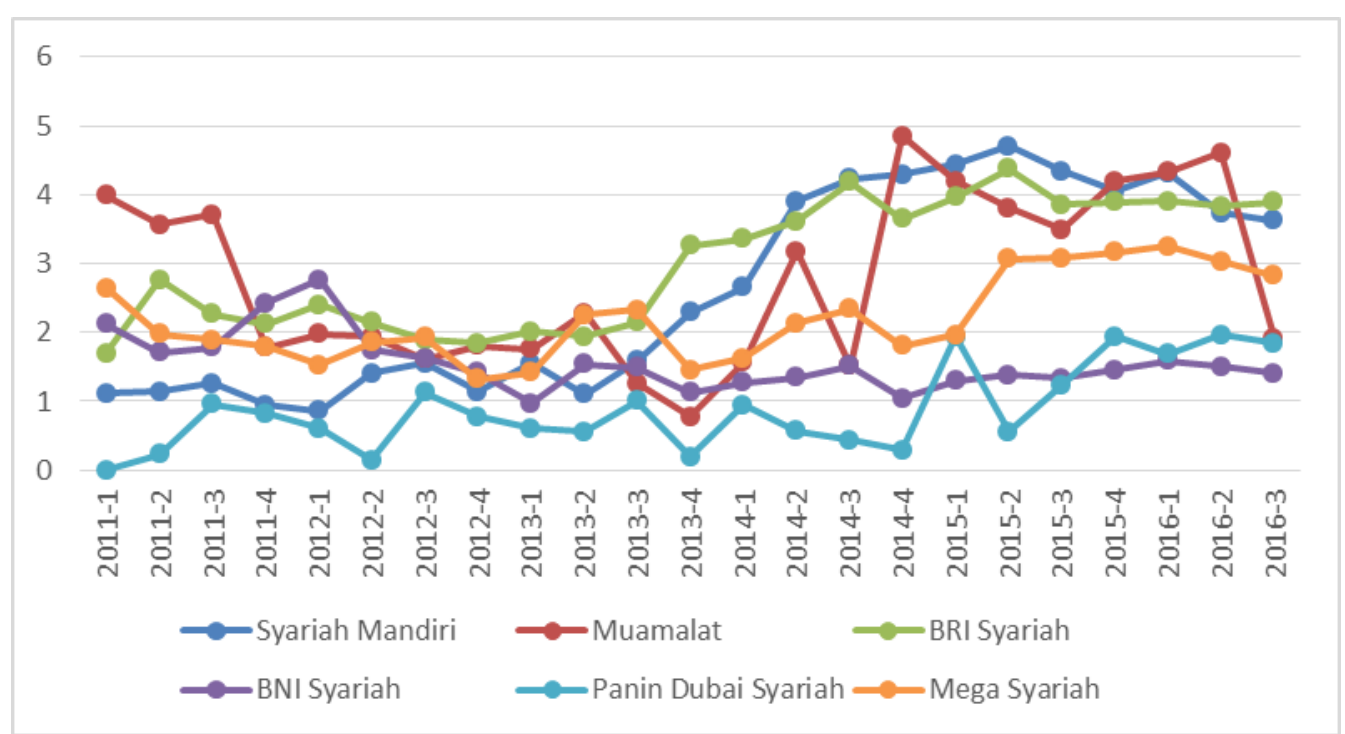

Sumber: Data olahan dari Laporan Triwulan BPS-BPIH.

Pada diagram diatas terlihat bahwa mulai dari tahun 2013 NPF dari mayoritas BPSBPIH bergerak naik yaitu NPF dari Bank Syariah Mandiri, Bank Muamalat, Bank BRI Syariah, Bank Pani Dubai Syariah dan Bank Mega Syariah. Hal ini terjadi bertepatan dengan waktu penerbitan APBPIH. Sehingga dapat disimpulkan bahwa keempat bank tersebut diatas menyalurkan dana BPIH kedalam pembiayaan yang buruk atau mengalami penurunan kualitas pembiayaan sehingga tidak menghasilkan keuntungan melainkan kerugian. Bank BNI Syariah mengalami kondisi yang berbeda. NPF Bank BNI Syariah mengalami sedikit penurunan pada saat APBPIH mulai berjalan. Artinya Bank BNI Syariah berhasil menjaga kualitas pembiayaannya.

Pengaruh Capital Adequacy Ratio (CAR) terhadap Return on Assets (ROA). Hasil uji $t$ statistik CAR tidak berpengaruh terhadap ROA pada seluruh bank syariah penerima (BPIH) menghasilkan nilai probabilitas 0.7613 (Tabel 2). Secara individual CAR berpengaruh terhadap ROA di bank Mandiri, Muamalat, Panin Dubai Syariah, dan Mega Syariah. CAR berpengaruh terhadap ROA di Bank BRI Syariah dan BNI Syariah (Tabel 3).

Pengaruh CAR positif dan signifikan terhadap ROA Bank Syariah Mandiri, Bank Muamalat dan Bank Mega Syariah. Hal ini terjadi dikarenakan terelisasinya resiko pembiayaan berupa kerugian akibat macet atau gagal pembayaran dari pihak debitur (default) yang kemudian harus 'diserap' atau ditanggung oleh oleh CAR. Pembayaran yang macet dari debitur kepada bank dalam dunia perbankan disebut dengan Non Perfoming Loan (NPL) bagi bank konvensional atau Non Performing Financing (NPF) bagi bank syariah. Menurut Shingjergji dan Hyseni (2015) NPL atau NPF berpengaruh negatif terhadap CAR. Pada gambar 2 terlihat bahwa Bank Syariah Mandiri, Bank Muamalat dan Bank Mega syariah mengalami lonjakan tingkat Non Performing Financing (NPF) yang berpotensi menciptakan kerugian dan menurunkan ROA. Oleh karena itu CAR berpengaruh positif pada ROA di bank Mandiri, Muamalat, Panin Dubai Syariah, dan Mega Syariah.

Pada BRI Syariah dan BNI Syariah, CAR berpengaruh negatif dan signifikan terhadap ROA. Kondisi ini terjadi karena selama periode penelitian bank tersebut menempatkan dana yang terlalu besar untuk menanggung resiko pembiayaan (CAR). CAR BRI Syariah sebesar 
14,47 persen, dan CAR BNI Syariah sebesar 17,56 persen, sementara yang disyaratkan oleh Bank Indonesia yaitu 8 persen. Kondisi ini menjadikan BRI Syariah dan BNI Syariah berada dalam kondisi yang terlalu solvabel, namun kehilangan potensi meraih keuntungan operasional.

Pada kondisi yang relatif normal CAR tidak berpengaruh terhadap ROA namun bisa berubah, CAR menjadi berpengaruh positif dan signifikan terhadap ROA bila sebuah bank memiliki tingkat NPF yang tinggi sehingga resiko pembiayaan terealisasi. Seperti yang terjadi pada Bank Syariah Mandiri, Bank Muamalat dan Bank Mega Syariah sepanjang periode penelitian ini. Kondisi lain CAR akan berpengaruh negatif terhadap ROA bila sebuah bank berada dalam kondisi terlalu solvabel seperti yang dialami oleh Bank BRI Syariah dan BNI Syariah sepanjang periode penelitian ini.

Pengaruh Financing to Deposit Ratio (FDR) Terhadap Return on Asset (ROA). FDR berpengaruh positif dan signifikan terhadap ROA di seluruh bank syariah penerima setoran biaya penyelenggaran ibadah haji (BSP BPIH). Nilai probabiltas adanya 0,0005 (Tabel 2). Secara individu FDR berpengaruh positif dan signifikan di bank Muamalat dan Bank Mega Syariah sedangkan di Bank Syariah Mandiri, BRI Syariah, BNI Syariah, dan Panin Dubai Syariah, FDR berpengaruh negatif dan signifikan (Tabel 3).

Secara teori, FDR sesuai dengan namanya adalah rasio perbandingan jumlah pembiayaan dengan jumlah dana pihak ketiga (deposan). Semakin tinggi nilai FDR berarti semakin tinggi pula kegiatan pembiayaan yang dilakukan oleh bank. Bilamana pembiayaan yang dilakukan adalah pembiayaan yang baik dan produktif dengan menghasilkan margin keuntungan, maka peningkatan FDR akan memberikan pengaruh yang positif dan signifikan terhadap ROA seperti yang terjadi dalam kasus ini pada Bank Muamalat.

FDR berpengaruh negatif dan signifikan pada ROA Bank BRI Syariah, BNI Syariah dan Bank Panin Dubai Syariah. Hal ini disebabkan oleh perlambatan ekonomi domestik yang menyebabkan bank-bank tersebut berada dalam kondisi yang tidak kondusif untuk melakukan pembiayaan karena akan beresiko menghasilkan pembiayaan yang buruk atau Non Performing Financing (NPF) sehingga pada akhirnya menurunkan ROA (Buchory, 2014).

Pengaruh Biaya Operasional Terhadap Pendapatan Operasional (BOPO) Terhadap Return On Assets (ROA). BOPO berpengaruh negatif dan signifikan terhadap ROA pada tingkat signifikansi 1 persen dengan koefisien sebesar -0,069832 diseluruh bank syariah penerima setoran biaya penyelenggaran ibadah haji (BSP BPIH). Artinya setiap kenaikan 1 persen BOPO akan berpengaruh pada perubahan kenaikan ROA sebesar 0,069832 persen.

Dalam pengujian pada masing-masing bank didapatkan hasil yang sama pula bahwa BOPO berpengaruh negatif dan signifikan terhadap ROA. Rata- Rata BOPO dari keseluruhan BPS-BPIH adalah 87,16899 persen lebih tinggi dari yang ditetapkan Bank Indonesia dalam Surat Edaran No.15/7/DPNP tanggal 8 Maret 2013 yaitu sebesar 85 persen. Hal ini menunjukan bahwa efisiensi dari BPS-BPIH sepanjang periode penelitian adalah buruk. Dengan kata lain BPS-BPIH menjalankan operasionalnya dengan tidak efisien.

Pengaruh APBPIH, CAR, FDR dan BOPO Secara Simultan Terhadap ROA Bank Umum Syariah Penerima BPIH (BPS-BPIH). Hasil uji $F$ regresi data panel sekaligus untuk semua BPS-BPIH menunjukan nilai $F$ statistik sebesar 179,9286 dengan probabilitas (Fstatistik) sebesar 0,000 atau lebih kecil dari a 0.005) sehingga disimpulkan bahwa APBPIH, 
CAR, FDR dan BOPO secara bersama-sama dan simultan berpengaruh positif dan signifikan terhadap ROA BPS-BPIH. Pengaruh yang signifikan ini menunjukan bahwa Penerbitan Aturan Penyetoran BPIH (APBPIH), kecukupan modal yang diproksi dengan CAR, likuiditas yang diproksi dengan FDR, serta efisiensi yang diproksi dengan BOPO ikut menyumbang dalam menghasilkan laba bagi BPS-BPIH. Hal ini di konfirmasi dengan hasil uji $F$ pada regresi individual masing - masing bank BPS-BPIH yang menunjkan hasil yang sama bahwa APBPIH, CAR, FDR dan BOPO secara bersama-sama dan simultan berpengaruh positif dan signifikan terhadap ROA BPS-BPIH seperti yang dapat dilihat pada tabel berikut:

Tabel 4. Hasil Uji F Statistik BPS-BPIH, Sekaligus dan Individual

\begin{tabular}{lllll}
\hline Bank & F-statistic & $\begin{array}{l}\text { Prob } \\
\text { statistic })\end{array}$ & $\begin{array}{l}\text { (F- } \\
\text { R-squared }\end{array}$ & $\begin{array}{l}\text { Adjusted } \\
\text { R-squared }\end{array}$ \\
\hline $\begin{array}{l}\text { BPS-BPIH } \\
\text { Sekaligus) }\end{array}$ & $179.9286^{*}$ & 0.000 & 0.934070 & 0.928879 \\
\hline Syariah Mandiri & $605.4387^{*}$ & 0.000 & 0.979454 & 0.977837 \\
\hline Muamalat & $134.5306^{*}$ & 0.000 & 0.913741 & 0.906949 \\
\hline BRI Syariah & $109.1691^{*}$ & 0.000 & 0.895790 & 0.887584 \\
\hline BNI Syariah & $222.8643^{*}$ & 0.000 & 0.946087 & 0.941842 \\
\hline $\begin{array}{l}\text { Panin Dubai } \\
\text { Syariah }\end{array}$ & $149.9450^{*}$ & 0.000 & 0.921916 & 0.915767 \\
\hline Mega Syariah & $658.7783^{*}$ & 0.000 & 0.981087 & 0.979597 \\
\hline
\end{tabular}

*: level signifikansi 1\%. Sumber: Data olahan EViews 8

Nilai koefisien determinasi $R$-squared sebesar 0,934070 dan Adjusted $R$-squared sebesar 0,928879. Hal ini menunjukkan bahwa APBPIH CAR, FDR dan BOPO mampu menjelaskan variasi perubahan variabel terikat yaitu ROA sebesar 93,41 persen, sisanya 6.59 persen perubahan ROA dijelaskan oleh variabel lain. Dengan demikian model yang dibangun, tergolong baik.

\section{KESIMPULAN}

Aturan Penyetoran Biaya Penyelenggaran Ibadah Haji (APBPIH), FDR, BOPO berpengaruh secara signifikan terhadap ROA pada pengujian bank syariah secara menyeluruh. Secara individu, APBPIH juga berpengaruh terhadap ROA. Namun pengaruhnya berbeda-beda, tergantung pada Non Performing Financing (NPF) masingmasing.

Capital Adequacy Ratio (CAR) tidak berpengaruh terhadap ROA pada pengujian bank syariah secara menyeluruh. Pada pengujian secara individu, CAR tidak berpengaruh terhadap ROA, hanya terjadi di Panin Dubai Syariah. Pengaruh CAR terhadap ROA, beragam dimasing-masing. 
Financing to Deposit Ratio (FDR) berpengaruh secara signifikan terhadap ROA pada pengujian bank syariah secara menyeluruh. Pada pengujian secara individu, FDR berpengaruh terhadap ROA, di Bank Muamalat, BRI Syariah, BNI Syariah, Panin Dubai Syariah. Pada bank Syariah Mandiri dan bank Megar, FDR tidak berpengaruh pada ROA.

BOPO berpengaruh terhadap ROA pada pengujian bank syariah seracana menyeluruh dan secara individu, Secara simultan APBIP, CAR, FDR dan BOPO berpengaruh terhadap ROA pada pengujian secara menyeluruh dan secara individu.

\section{DAFTAR PUSTAKA}

Alamsyah, Halim. 2012. Perkembangan dan Prospek Perbankan Syariah Indonesia: Tantangan Dalam Menyongsong MEA 2015.

http://www.bi.go.id/id/ruang-media/pidato-dewangubernur/documents/6bf00812e40b4d0cb140ea80239c4966perkembanganprospekpe rbankansyariahindonesiamea201.pdf , 13 April 2012.

Antonio, M.S. 2001. Bank Syariah Dari Teori ke Praktik. Gema Insani Press Jakarta.

Amelia, E. 2015. Financial Ratio And Its Influence To Profitability In Islamic Banks. Allqtishad. Vol. 7 No. 2.

Bank Indonesia. 2011. PBI No. 13/1/PBI/2011 tentang Penilaian Tingkat Kesehatan Bank Umum.

http://www.bi.go.id/id/peraturan/perbankan/Documents/828aa23594154a89aeabab7dc 3103805pbi 130112.pdf

2015. Laporan Perekonomian Indonesia Tahun 2014.

http://www.bi.go.id/id/publikasi/laporantahunan/perekonomian/Pages/LPI 2014.aspx.

Bashir, Abdel-Hameed M. 2013. Determinants of Profitability in Islamic Banks: Some Evidence from the Middle East. Islamic Economic Studies, Vol. 11, No. 1. Available at SSRN: https://ssrn.com/abstract=3164222.

Buchory, H. A. 2014. Analysis of The Effect Capital, Credit Risk and Profitability in The Implementation of Banking Intermediation Function : Study on Regional Development Bank All Over Indonesia in 2012. Proceeding Kuala Lumpur International Business, Economics and Law Conference. Vol. 4, pp. 311-327.

Ben Naceur, S., \& Omran, M. 2010. The Effects of Bank Regulations, Competition, and Financial Reforms on Banks' Performance.

Dirjen Penyelenggaraan Haji dan Umrah Kementerian Agama RI. 2013. Dana Haji di Bank Konvensional Dialihkan Ke Bank Syariah. http:/haji.kemenag.go.id/v2/node/1251

Hakiim, N., Rafsanjani, H. 2016. Pengaruh Internal Capital Adequency Ratio (CAR), Financing To Deposit Ratio (FDR), dan Biaya Operasional Per Pendapatan Operasional (BOPO) dalam Peningkatan Profitabilitas Industri Bank Syariah di Indonesia. Jurnal Aplikasi Manajemen. Vol 14 No 1, 2016.

Harianto, S. 2017. Rasio Keuangan Dan Pengaruhnya Terhadap Profitabilitas Pada Bank Pembiayaan Rakyat Syariah di Indonesia. Esensi: Jurnal Bisnis dan Manajemen Volume 7 (1), Halaman 41.

Hassan, M. K., \& Bashir, A. H. M. 2003. Determinants of Islamic banking profitability. 10th ERF Annual Conference. Morocco, Vol. 7.

Kurniati, R.A. \& Purwohandoko. 2017. Influence Of Third-Party Funds, Car, NPF And FDR Towards The Return on Assets of Islamic Banks in Indonesia. Jurnal IImiah Bidang Akuntansi dan Manajemen. Vol. 14 No. 2 (2017).

Olarewaju, O. M., \& Akande, J. O. 2016. An Empirical Analysis of Capital Adequacy Determinants in Nigerian Banking Sector. International Journal of Economics and Finance. Vol 8 No. 12, p.132. 
Analisis Kinerja Bank Syariah ...

Saepujaman Saepujaman, Levyda Levyda \& Heri Ispriyahadi

Otoritas Jasa Keuangan (OJK). 2016. Laporan Keuangan Perbankan. http://www.ojk.go.id/id/kanal/perbankan/data-dan-statistik/laporan-keuanganperbankan/Default.aspx.

Sahara, A. Y. Y. 2013. Analisis Pengaruh Inflasi, Suku Bunga BI, dan Produk Domestik Bruto Terhadap Return On Asset Bank Syariah di Indonesia. Jurnal IImu Manajemen. Vol 1, No.1.

Swandayani, D. M., dan Kusumaningtias, R. 2012. Pengaruh Inflasi, Suku Bunga, Nilai Tukar Valas dan Jumlah Uang Beredar terhadap Profitabilitas pada Perbankan Syariah di Indonesia Periode 2005-2009. AKRUAL: Jurnal Akuntansi. Vol 3, No. 2, 147-166. 